\title{
PENGARUH PERPANJANGAN LINTAS KERETA API TERHADAP ANGKUTAN ELF
}

\author{
Dr. I Made Suraharta, MT \\ Dosen STTD \\ Jl. Raya Setu No. 89, Cibuntu, \\ Cibitung, Bekasi 17520 \\ Telp./Fax : (021) 8254640
}

\author{
Drs. Fauzi, MT \\ Dosen STTD
}

J1. Raya Setu No. 89, Cibuntu,

Cibitung, Bekasi 17520

Telp./Fax : (021) 8254640

\author{
Purwatiningsih, SH, MM \\ Dosen STTD \\ J1. Raya Setu No. 89, Cibuntu, \\ Cibitung, Bekasi 17520 \\ Telp./Fax : (021) 8254640
}

\author{
Ir. Djoko Septanto, MM \\ Dosen STTD \\ J1. Raya Setu No. 89, Cibuntu, \\ Cibitung, Bekasi 17520 \\ Telp./Fax : (021) 8254640
}

\author{
Agus Sembodo, S.SiT \\ Instruktur STTD \\ J1. Raya Setu No. 89, Cibuntu, \\ Cibitung, Bekasi 17520 \\ Telp./Fax : (021) 8254640
}

\begin{abstract}
ABSTRAKSI
Dalam rangka peningkatan pelayanan terhadap pengguna jasa Kereta Rel Listrik Jabodetabek khususnya pelanggan didaerah bekasi sampai dengan cikarang yaitu tentang keberadaan angkutan Elf yang rutenya sejajar dan berimpit dengan angkutan Kereta Rel Listrik.

Dan oleh karena itu untuk mencegah hal hal yang tidak diinginkan serta melihat dampak dari perpanjangan lintas tersebut maka akan diteliti apakah akibat perpanjangan lintas tersebut akan berpengaruh atau tidak terhadap angkutan umum elf yang telah terlebih dahulu melayani rute bakasi sampai dengan cikarang.karena bila Kereta Rel Listrik telah beroperasi pada lintas tersebut maka angkutan ELF hanya mendapat penumpang dari kantong kantong penumpang seperti ; pasar baru bekasi - terminal bekasi- bulak kapal dan tol timur. Sedang dari bulak kapal sampai dengan cikarang paraktis akan menggunakan Kereta Rel Listrik sampai dengan tujuan yaitu cikarang.

Alasan Menggunakan Kereta Rel Listrik : Persentase alasan menggunakan Kereta Rel Listrik terbesar adalah biaya murah dengan kisaran $39 \%$ atau sejumlah 39 responden, dimana alasan cepat mempunyai persentase terbesar kedua sebesar $31 \%$ yaitu sejumlah 31 responden, selanjutnya alasan aman mempunyai persentase ketiga sebesar $14 \%$ atau sejumlah 14 responden , alasan keempat yaitu jarak dekat dengan persentase $10 \%$ atau sejumlah 10 responden dan persentase terkecil yaitu alasan lainnya dengan persentase $6 \%$ atau sekitar 6 responden.

Dengan beroperasinya perpanjangan Kerata cukup mempengaruhi namun Angkutan mobil penumpang Elf masih mendapat angkutan dari kantong-kantong penumpang disepanjang rute dari stasiun bekasi - terminal bekasi - bulak kapal - Tambun sampai dengan Cikarang.
\end{abstract}

Kata Kunci: Angkutan Tumpang Tindih, KRL, ELF Cikarang - Bekasi

\section{ABSTRACT}

In order to improve the service to users of Electric Railway Train in Jabodetabek, the customers of Bekasi until Cikarang in particular is about the presence of Elf shuttles that routed in parallel and coincides with the Electric Railway Train transport.

And therefore to prevent the unwanted things and to see the impact of the extension of the traffic which will be examined whether as a result of the extension of the traffic will affect or not to the public elf tramsport who has been the first one to service the route of Bekasi-Cikarang because if Electric Railway Train has been operating in the route then the elf transports will only get passengers from "bags of passengers" like; Pasar Baru Bekasi-Bekasi Terminal and Tol Timur while from Bulak Kapall to Cikarang will use the Electric Railway Train practically.

The reasons to sse Light rail: the largest percentage of reasons to use Light rail is the low cost with the range of $39 \%$ or a total of 39 respondents, which to be fast as the reason has the 
second largest percentage of $31 \%$ or total a number of 31 respondents, the security reasons has the third positions with $14 \%$ or a number of 14 respondents, the fourth reason is the close range with the percentage of $10 \%$ or a 10 respondents and the lowest percentage is another reason with the percentage of $6 \%$ or about 6 respondents.

With the operation of the train extension will be influence enough yet Elf as the passenger car transport still get transport from "the bags of passengers" along the route from Bekasi Station - Bekasi Terminal - Bulak Kapal - Tambun to Cikarang.

Keywords: Overlapping Transport, Electric Railway Train, Elf (Cikarang-Bekasi)

\section{PENDAHULUAN}

\section{A. LATAR BELAKANG}

Dalam rangka peningkatan pelayanan terhadap pengguna jasa KERETA REL LISTRIK jabodetabek khususnya pelanggan didaerah bekasi sampai dengan cikarang dimana yang sebelumnya pelayanan komuter line hanya sampai stasiun bekasi menurut rencana akan diperpanjang sampai dengan daerah cikarang kabupaten bekasi sehingga ada hal hal yang harus diantisipasi yaitu tentang keberadaan angkutan ELF yang rutenya sejajar dan berimpit dengan angkutan KERETA REL LISTRIK tersebut, ..sedang informasi dari PT Persero KA Daops 1jakarta rencana perpanjangan lintas tersebut akan segera dioperasikan pada sekitar akhir tahun 2017.

Dan oleh karena itu untuk $m$ encegah hal hal yang tidak diinginkan serta melihat dampak dari perpanjangan lintas tersebut maka akan diteliti apakah akibat perpanjangan lintas tersebut akan berpengaruh atau tidak terhadap angkutan umum elf yang telah terlebih dahulu melayani rute bakasi sampai dengan cikarang.karena bila KERETA REL LISTRIK telah beroperasi pada lintas tersebut maka angkutan ELF hanya mendapat penumpang dari kantong kantong penumpang seperti ; pasar baru bekasi terminal bekasi- bulak kapal dan toll timur.sedang dari bulak kapal sampai dengan cikarang paraktis akan menggunakan KERETA REL LISTRIK sampai dengan tujuan yaitu cikarang.

\section{B. IDENTIFIKASI MASALAH}

1. Pada saat perpanjangan lintas KERETA REL LISTRIK tersebut doperasikan secara penuh maka penumpang yang bertujuan ke tol timur, bulak kapal, 
tambun, cibitung dan cikarang yang tidak menggunakan roda dua dan empat yang secara otomatis tidak akan menggunakan elf dan akan langsung ke stasiun - stasiun tujuan sampai dengan stasiun cikarang

2. Akibat dari perpanjangan lintas KERETA REL LISTRIK tersebut maka kendaraan angkutan penumpang elf akan kehilangan penumpang pada kantong - kantong penumpang untuk tujuan pasar bekasi/terminal, bulak kapal/tol timur, tambun sampai dengan cikarang maupun sebaliknya.

3. Informasi dari dishub kota bekasi jumlah angkutan elf yang melayani trayek lintas bekasi cikarang berjumlah empat ratus kendaraan dimana setliap harinya dari jumlah tersebut ada sekitar delapan puluh persen yang beroperasi dan hal tersebut diperkirakan akan menjadi masalah jika jumlah penumpang pada kantong kantong yang ada akan mengalami penurunan penumpang

4. Dan apabila hal tersebut pada butir tiga benar- benar akan terjadi maka dapat menimbulkan penurunan pendapatan bagi operator elf termasuk pengemudi maka akan mengakibatkan kecemburuan sosial dan kemungkinan akan berakibat terjadinya insiden yang tidak diinginkan.

5. Sementara itu dengan adanya perpanjangan lintas yang bersamaan dengan penambahan jalur menjadi empat jalur maka pengguna pengguna jalan yang melintas pada perlintasan sebidang pada jalur tersebut harus waspada dan lebih berhat hati.karena pada saatsebut

6. Waktu tempuh angkutan umum ELF antara bekasi sampai dengan cikarang lebih kurang antara 60 sampai dengan 75 menit sehingga lebih lambat dari pada KERETA REL LISTRIK yang mempunyai waktu tempuh sekitar 15 sampai dengan 20 menit

\section{BATASAN MASALAH}

Dari hasil identifikasi permasalahan tersebut diatas dan terbatasnya waktu pelaksanaan survey serta dana yang tersedia, maka permasalahan hanya dibatasi pada perpanjangan lintas KERETA REL LISTRIK dan pengaruh yang tejadi akibat menurunya penumpang yang berakibat pula pada menurunya pendapatan operator elf dengan trayek bekasi cikarang,

\section{PERUMUSAN MASALAH}

Dari batasan permasalahan tersebut diatas maka agar penyelesaian masalah tersebut dapat lebih mudah dipecahkan dan hasilnya terukur maka permasalahan tersebut diatas dirumuskan sebagai berikut : 
Apakahn degan adanya perpanjangan lintas KERETA REL LISTRIK berpegaruh terhadap junmlah penumpang angkutan umum elf tryej bekasi - cikarang ?

\section{E. TUJUAN PENELITIAN}

Tujuan dari penelitian ini adalah untuk mengetahui seberapa jauh adanya pengaruh terhadap jumlah penumpang angkutan umum elf dan atau akibat adanya perpanjangan lintas KERETA REL LISTRIK lintas bekasi - cikarang.tersebut bahkan tidak ada sama sekali . .

\section{F. URGENSI PENELITIAN}

Penelitian ini perlu dilakukan mengingat jumlah angkutan umum yang sangat banyak sehingga bila jumlah penumpang menurun dan berakibat kepada pendapatan operator pengemudi serta keluarganya yang hal akibat adanya angkutan umum lain yang melayani yakni KERETA REL LISTRIK maka dikhawatirkan kemungkinan akan terjadi insiden yang sangat tidak kita inginkan dan jauh jauh hari kita harus sudah mendapatkan solusi penaganannya sehingga insiden dapat diminimalkan dan bahkan dapat dihilangkan,

\section{STUDI PUSTAKA}

\section{A. ASPEK LEGALITAS}

1. Undang-Undang Republik Indonesia No. 23 Tahun 2007 tentang Perkeretaapian

2. Undang - undang No 22 Tahun 2007 tentang lalu lintas dan angkutan jalan

3. Peraturan Pemerintah No 56 Tahun 2009 tentang penyelenggaraan prasarana perkeretaapian

4. Peraturan pemerintah No xx Tahun 2009 tentang penyelenggaraan angkutan umum dijalan

\section{B. ASPEK TEORITIS}

Grafik perjalanan Kereta Rel Listrik ( Gapeka ) adalah perencanaan operasi Kereta Rel Listrik yang dan di gambarkan dalam bentuk garis yang menunjukan Perkeretaapian adalah satu kesatuan sistem yang terdiri atas prasarana, sarana dan sumber daya manusia serta norma kriteria persyaratan stasiun, jarak, kecepatan dan posisi perjalanan Kereta Rel Listrik mulai dari berangkat, bersilang, bersusulandan berhenti yang digambarkan secara grafis untuk pengaturan perjalanan Kereta Rel Listrik.

1. Jaringan pelayanan perKereta Rel Listrikan terdiri atas jaringan pelayanan perkeretaapian antar kota dan jaringan pelayanan perkeretaapian perkotaan 
2. Kapasitas lintas harus memperhatikan kecepatan, jarak antar dua stasiun atau petak blok dan fasilitas operasi

3. Jaringan pelayanan perkeretaapian perkotaan dapat melampaui wilayah stu propinsi, stu kabupaten /kota dalam satu propinsi dan atau berada dalam wilayah satu kabupaten / kota

4. Jaringan pelayanan perkeretaapian perkotaan diselenggarakan dengan ciri ciri pelayanan ;

Menghubungkan beberapa stasiun perkotaan, melayani banyak penumpang berdiri, memiliki sifat perjalanan ulang alik /komuter, melayani trayek tetap, memiliki jarak dan waktu tempuhpendek dan melayani kebutuhan angkutan penumpang didlam kota/komuter yang berasal dari derah sub urban menuju pusat kota (urban) untuk melakukan aktifitas sehari hari.

5. Standar pelayanan minimum angkutan orang terdiri dari standar pelayanan minimum di stasiun dan standar pelayanan minimum dalam perjalanan,

6. Standar pelayanan minimumdi stasiun meliputi ;

Jadwal, harga tiket, nama dan nomor Kereta Rel Listrik, jenis Kereta Rel Listrik, stasiun pemberangkatan, stasiun transit dan stasiun tujuan, lintas yang dilewati dan tingkat pelayanan

7. Standar pelayanan perkeretaapian dalam perjalanan untuk Kereta Rel Listrik perkotaan adalah tersedia fasilitas pintu dan jendela, tempat duduk, lampu penerangan, kipas angin, rak bagasi, fasilitas khusus untuk penyandang cacat/wanita hamil/anak balita/orang lanjut usia dan orang sakit, fasilitas pegangan untuk penumpang berdiri dan mematuhi Kereta Rel Listrik 


\section{A. POLA PIKIR PENELITIAN}

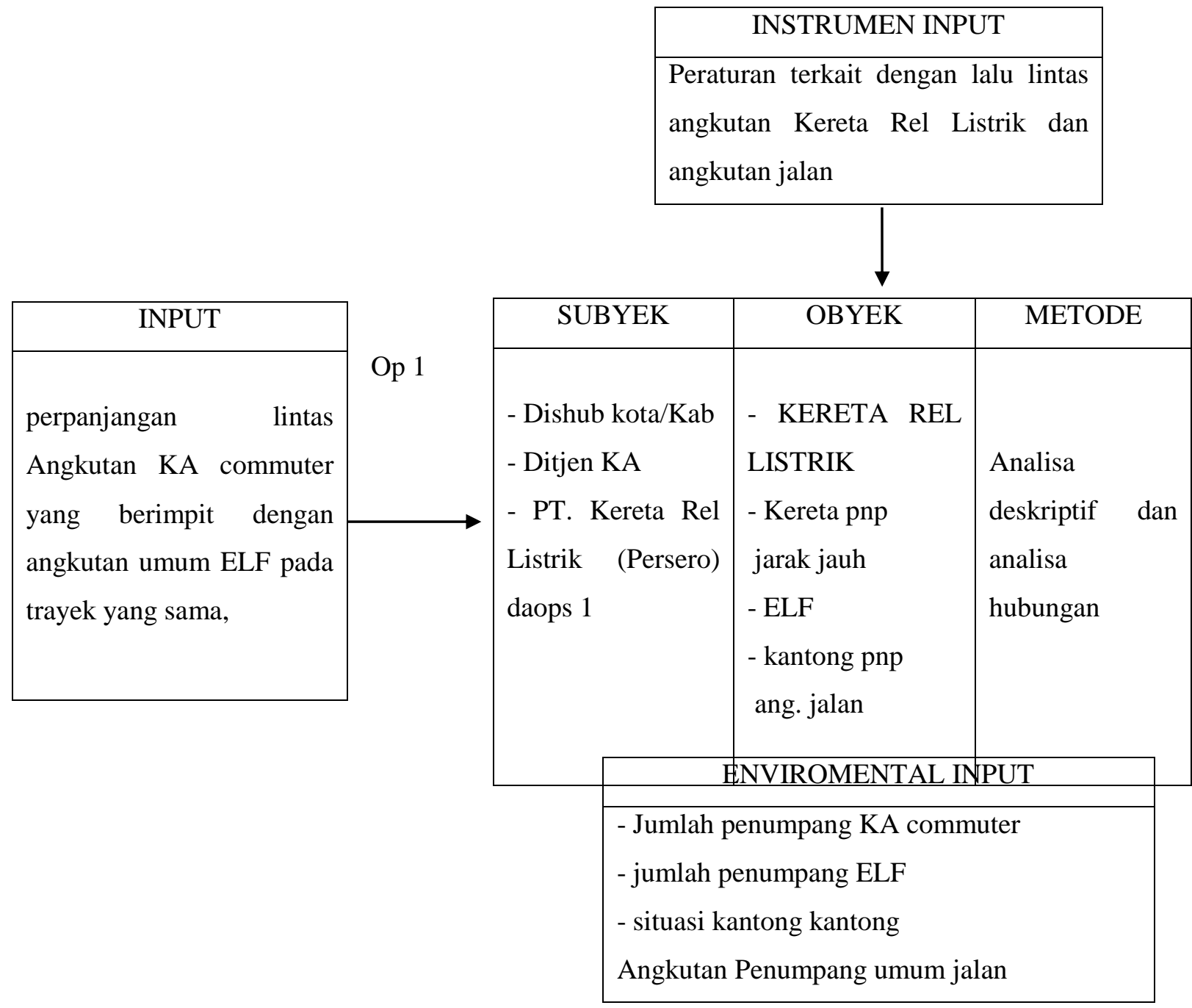

\begin{tabular}{|c|c|}
\hline OUTPUT & OUTCOME \\
\hline & keterpaduan \\
\hline Tersusunya & Pelayanan \\
\hline konsep & Angkuta umum \\
\hline penanganan & jalan ELF dan \\
\hline pelayanan & KA commuter \\
\hline angkutan & dapat berjalan \\
\hline umum & dengan aman \\
\hline ELF & dan teratur \\
\hline
\end{tabular}




\section{B. ALUR PIKIR PENELITIAN}

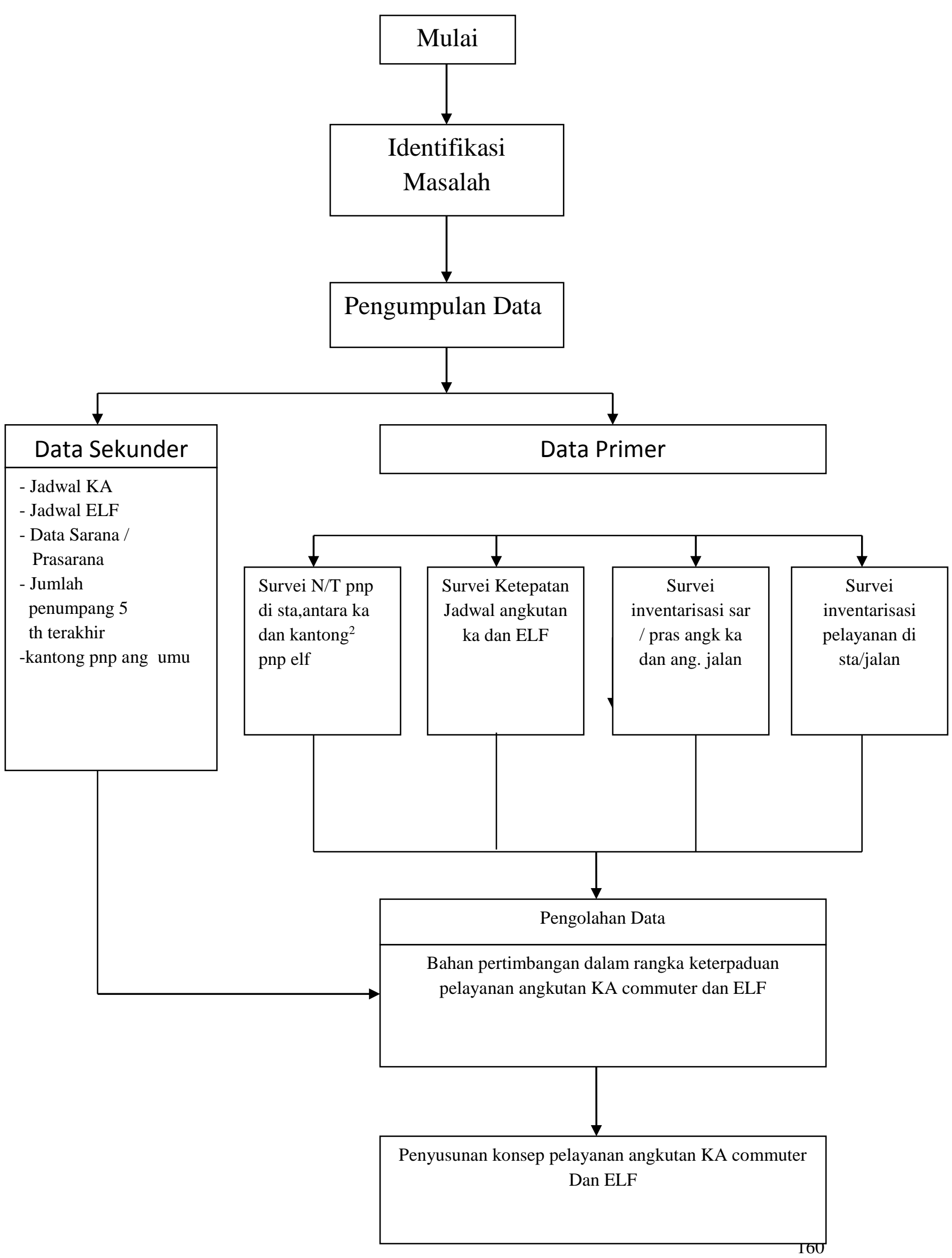




\section{METODE PENGUMPULAN DATA}

Pengumpulan data ini meliputi pengumpulan data sekunder yang didapat dari instansi terkait seperti Dinas Perhubungan pemda kabupaten/Kota diwilayah bekasi yang meliputs peta tata guna lahan, peta jaringan jalan, data penumpang elf 5 tahun terakhir dan jumlah kendaraan angkutan umum elf serta beberapa trayek terpilih untuk keperluan penelitian, serta PT KA daerah operasi 1 jakarta yang terdiri dari data penumpang 5 tahun terakhir, data saran a dan prasarana yang beroperasi pada lintas perpanjangan .data jalur, Ditjen ka yang meliputi kebijakan angkutan umum KA COMMUTERta lintas jakarta kota cikarang.

Sedang Data primer diambil dari hasil survey yang meliputi survey OD, survey lama perjalanan ELF dan KA, survey headway KERETA REL LISTRIK dan ELF, survey naik turun penumpang disetiap stasiun antara pada lintas bekasi - cikarang serta survey naik turun penumpang dan wawancara dikantong kantong penumpang angkutan umum yaitu terminal/pasar - bulak kapal /tol timur - tambun - cibitung dan cikarang, survey ketepatan jadwal melalui survey kedatangan dan keberangkatan ka dan ELF, survey inventarisasi sarana dan prasarana angkutan KERETA REL LISTRIK dan angkutan jalan.

\section{PELAKSANAAN SURVEY}

Survey yang dilakukan adalah survey statis dan dinamis untuk angkutan umum elf mulai dari stasiun BEKASI sampai dengan terminal cikarang dengan melalui KANTONG KANTONG PENUMPANG ANGKUTAN UMUM JALAN seperti DI TERMINAL BEKASI - BULAK KAPAL /TOL TIMUR - TAMBUN - CIBITUNG SAMPAI DENGAN TERMINAL CIKARANG .

\section{E. METODE ANALISA}

Metode yang digunakan adalah dengan Pendekatan metode DESKRIPTIF yakni melalui analisa kinerja naik turun penumpang, analisa waktu tempuh perjalanan serta metode analisa HUBUNGAN melalui koofisien korelasi partial dan koofisien penentu partial dalam rangka untuk mengetahui hubungan dan pengaruh akibat adanya perpanjangan lintas pelayanan KERETA REL LISTRIK terhdap angkutan penumpang umum ELF. 


\section{ANALISA DAN PEMBAHASAN}

Berdasarkan data yang telah dikumpulkan analisis yang dilakukan :

\section{A. Karakteristik Penumpang Angkutan Elf Bekasi - Cikarang}

Karakteristik Penumpang Angkutan Elf Bekasi - Cikarang diuraikan dan dipersentasikan pada pembahasan di bawah ini :

\section{Jenis kelamin}

Berdasarkan hasil analisis yang dilakukan terhadap 100 orang responden di Stasiun Bekasi, dapat diketahui proporsi jenis kelamin responden. Mayoritas pengguna jasa di Stasiun Bekasi adalah berjenis kelamin Wanita dengan persentase 52\% atau sejumlah 52 orang, sedangkan untuk jumlah responden Pria persentasenya sebesar $48 \%$ atau sejumlah 48 orang. Untuk keterangan selengkapnya dapat dilihat pada Gambar ini.

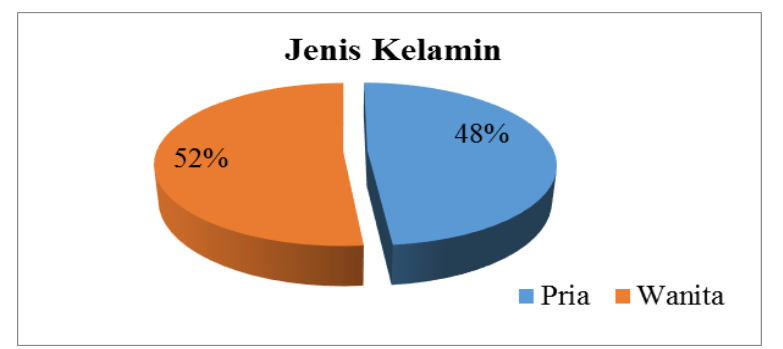

Sumber: Hasil analisis

\section{GAMBAR : PERSENTASE JENIS KELAMIN}

\section{Jenis pekerjaan}

Output dari survei pada kategori status pekerjaan yaitu mengetahui proporsi terbesar dari pekerjaan responden. Untuk selengkapnya dapat dilihat pada Gambar ini.

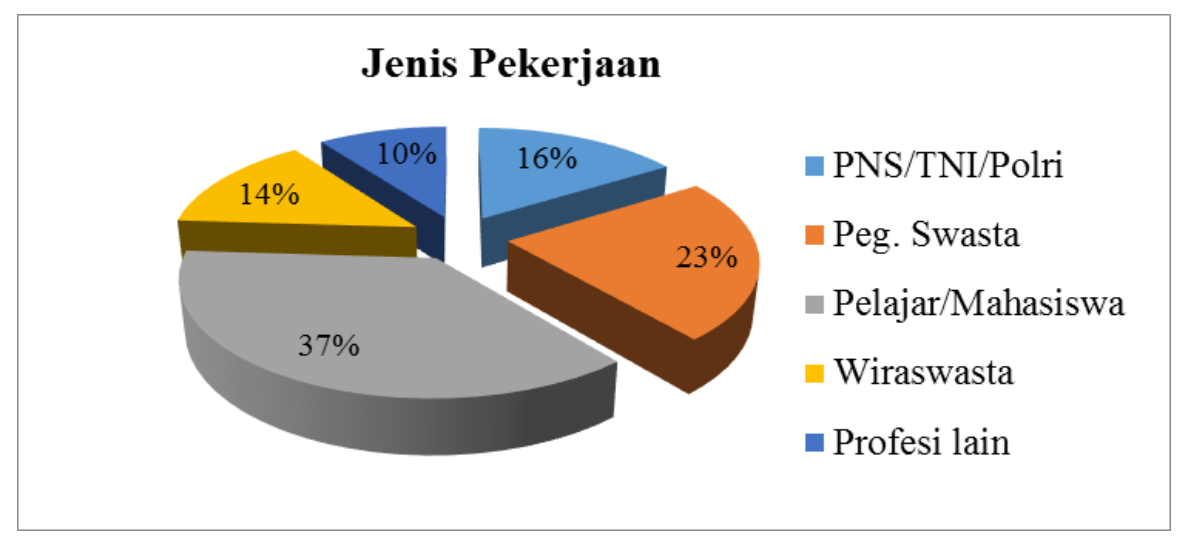

Sumber: Hasil analisis

GAMBAR : PERSENTASE JENIS PEKERJAAN 
Dari Gambar terlihat bahwa persentase pekerjaan dari responden terbesar adalah Pelajar/Mahasiswa sebesar 37\% atau sejumlah 37 responden, sedangkan persentase terbesar kedua adalah Pegawai Swasta sebesar 23\% yaitu sejumlah 23 responden disusul berurutan oleh PNS/TNI/POLRI sebesar 16\% yaitu sejumlah 16 responden dan wiraswasta hanya sejumlah 14 orang atau setara dengan 14\%, sehingga urutan terakhir terletak pada jenis pekerjaan lain-lain yaitu sebesar $10 \%$ atau sejumlah 10 orang.

\section{Alasan Menggunakan Kereta Rel Listrik}

Persentase alasan menggunakan Kereta Rel Listrik terbesar adalah biaya murah dengan kisaran 39\% atau sejumlah 39 responden, dimana alasan cepat mempunyai persentase terbesar kedua sebesar $31 \%$ yaitu sejumlah 31 responden, selanjutnya alasan aman mempunyai persentase ketiga sebesar $14 \%$ atau sejumlah 14 responden, alasan keempat yaitu jarak dekat dengan persentase $10 \%$ atau sejumlah 10 responden dan persentase terkecil yaitu alasan lainnya dengan persentase $6 \%$ atau sekitar 6 responden.

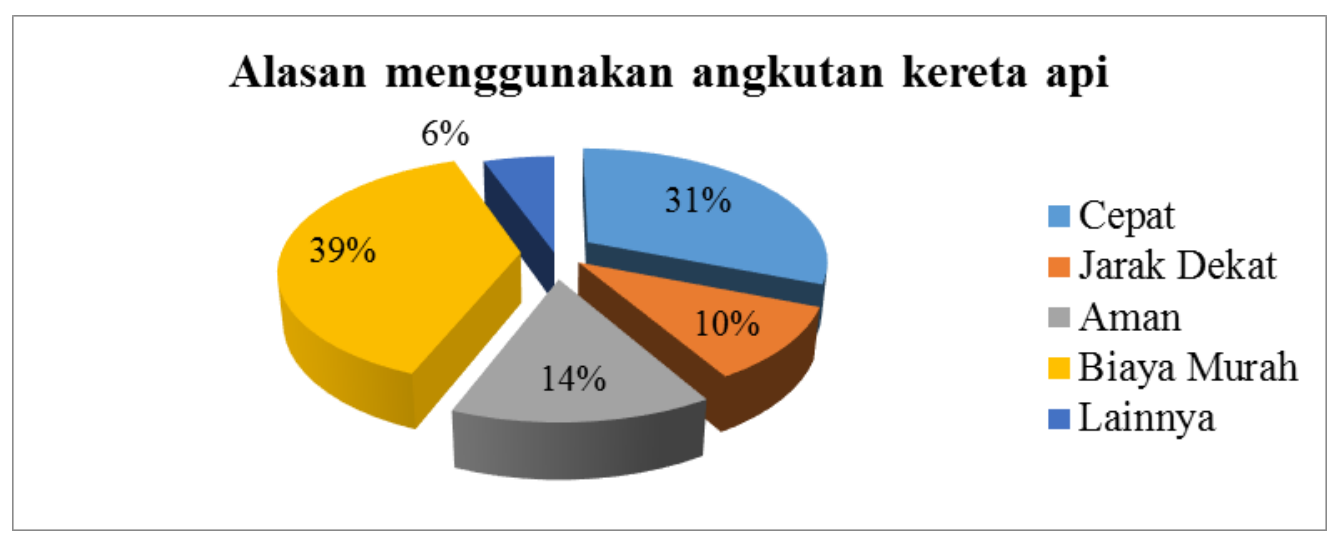

Sumber: Hasil analisis,

\section{GAMBAR : Persentase Alasan Menggunakan Kereta Rel Listrik}

\section{Keperluan Melakukan Perjalanan}

Persentase keperluan melakukan perjalanan terbesar adalah untuk bekerja dengan persentase $40 \%$ atau sejumlah 40 responden, sedangkan keperluanuntuk sekolah dengan persentase terbesar kedua sebesar $22 \%$ yaitu sejumlah 22 responden, selanjutnya keperluan rekreasi mempunyai persentase ketiga sebesar $16 \%$ atau sejumlah 16 responden, keperluan keempat yaitu untuk bisnis dengan persentase 14\% atau sejumlah 14 responden dan persentase terkecil yaitu keperluan lainnya dengan persentase $8 \%$ atau sekitar 8 responden sesuai dengan Gambar ini. 


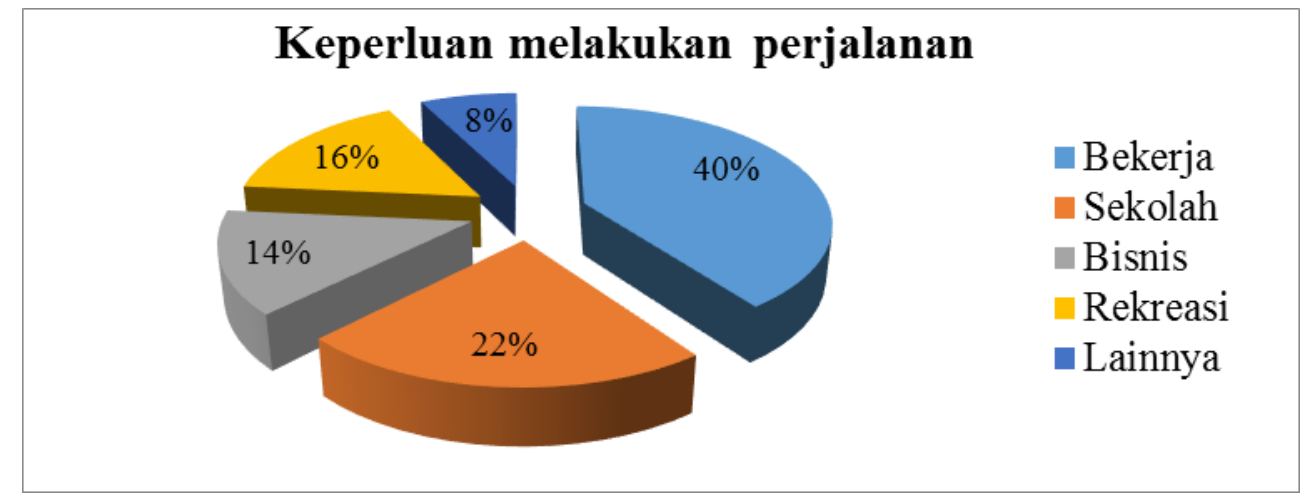

Sumber: Hasil analisis

\section{Gambar : Persentase Keperluan Melakukan Perjalanan}

\section{B. Analisis Kinerja Angkutan Penumpang Umum Elf Bekasi - Cikarang}

Hasil survey yang telah dilakukan mulai tanggal sampai dengan tanggal meliputi survey statis dengan hasil sebagai berikut :

Analisis Kinerja Angkutan Penumpang Umum Elf Bekasi - Cikarang

1. Dari hasil survey yang telah dilakukan yakni survey statis dan dinamis untuk angkutan kendaraan umum elf dapat dilihat bahwa komuter line menyumbangkan demand angkutan penumpang untuk elf ( survey dinamis ) sebanyak $36 \%$ sedang yang $64 \%$ didapat dari kantong kantong elf pada rute stasiun bekasi sampai dengan terminal cikarang .

sedang untuk survey penumpang statis menyumbangkan demand angkutan penumpang elf sebesar $100 \%$ tetapi hanya untuk sebagian kecil saja karena tergantung dari kerapatan dsari kedatangan kereta komuter line .sedang biasanya yang mendapatkan penumpang $100 \%$ hanya 1 sampai dengan 3 kendaraan angkutan elf saja yang lainnya hanya sekitar $36 \%$ saja.

2. Sedang untuk Kereta Rel Listrik jarak jauh baik yang datang pagi siang dan atau malam hari di stasiun bekasi hanya menyumnbangkan jumlah peenumpang sekitar 3 sampai dengan $4 \%$ saja.

3. Untuk kenyamanan penumpang dalam memilih KA KML DAN ATAU ELF diambil dari hasil wawancara dengan penumpang komuter line lintas jakarta /kota sampai dengan bekasi dan didapat hasil sebagai berikut :

a. Apabila kereta rel listrik diperpanjang lintassannya sampai dengan cikarang maka para pengguna kereta listrik KML akan memilih menggunakan Kereta Rel Listrik KML sampai dengan tujuan mereka seperti bulak kapal sampai demhan cikarang. 
b. Alasan para pengguna Kereta Rel Listrik KML tersebut adalah tarif yang terjangkau, sangat nyaman walaupun berdiri dan waktu tempuh yang lebih cepat dari pada angkuatan penumpang umum elf yang dimana para drivernya mempunyai hobby yang buruk suka ngetem dalam waktu yang cukup lama ( 3 -5 menit )

\section{KESIMPULAN DAN SARAN}

\section{A. KESIMPULAN}

Berdasarkan analisis data yang telah dilakukan, maka kesimpulan dari penelitian ini adalah sebagai berikut :

1. Karakteristik Penumpang Angkutan Elf Bekasi - Cikarang berdasarkan

Jenis kelamin : proporsi jenis kelamin responden. Mayoritas pengguna jasa di Stasiun Bekasi adalah berjenis kelamin Wanita dengan persentase 52\% atau sejumlah 52 orang, sedangkan untuk jumlah responden Pria persentasenya sebesar $48 \%$ atau sejumlah 48 orang.

Alasan Menggunakan Kereta Rel Listrik : Persentase alasan menggunakan Kereta Rel Listrik terbesar adalah biaya murah dengan kisaran 39\% atau sejumlah 39 responden, dimana alasan cepat mempunyai persentase terbesar kedua sebesar $31 \%$ yaitu sejumlah 31 responden, selanjutnya alasan aman mempunyai persentase ketiga sebesar $14 \%$ atau sejumlah 14 responden, alasan keempat yaitu jarak dekat dengan persentase $10 \%$ atau sejumlah 10 responden dan persentase terkecil yaitu alasan lainnya dengan persentase $6 \%$ atau sekitar 6 responden

2. Perpanjangan pengoperasian KERETA REL LISTRIK tidak menganggu kinerja angkutan mobil penumpang EFL

3. Angkutan mobil penumpang ELF masih mendapat angkutan dari kantong-kantong penumpang disepanjang rute dari stasiun bekasi - terminal bekasi - bulak kapal Tambun sampai dengan Cikarang

4. Kereta Rel Listrik diperpanjang lintassannya sampai dengan cikarang maka para pengguna kereta listrik KML akan memilih menggunakan Kereta Rel Listrik KML sampai dengan tujuan mereka seperti bulak kapal sampai demhan cikarang.

\section{B. SARAN}

Dari hasil kesimpulan yang disampaikan diatas, saran yang mudah-mudahan dapat dijadikan sebagai bahan pertimbangan untuk penelitian selanjutnya. sebagai berikut :

1. Dipandang perlu rute mobil penumpang ELF diusulkan sampai dengan Karawang 
2. Untuk keamanan penumpang ditanya ulang fasilitas naik dan turun penumpang seperti halted an fasilitas perlengkapan jalan

3. Harus adanya kajian ulang tentang :

a. Penataan ulang trayek angkutan Mobil penumpang ELF

b. Lama waktu tempuh angkutan Mobil penumpang ELF.

\section{DAFTAR PUSTAKA}

1. _ Undang-Undang Republik Indonesia Nomor 23 Tahun 2007 tentang Perkeretaapian

2. _ Undang-Undang Republik Indonesia Nomor 22 Tahun 2009 tentang Lalu Lintas Angkutan Jalan

3. _ _ Direktorat Jendral Bina Marga, 1997, Departemen Pekerjaan Umum RI, Manual Kapasitas Jalan Indonesia, -, Jakarta.

4. _ Keputusan Menteri Perhubungan No. 53 tahun 2000 tentang perpotongan dan/atau persinngungan antara jalur Kereta Rel Listrik dengan bangunan lain.

5. Suharso, Puguh, 2009, Metode penelitian kuantitatif, Indeks, Jakarta.

6. Harinaldi, 2005, Prinsip-prinsip Statistik untuk Teknis dan Sains, Erlangga, Jakarta.

7. Kountur, Ronny, 2005, Metode penelitian untuk penulisan Penelitian dan tesis, Pmp, Jakarta.

8. Manheim, Marvin L. "Fundamental of Transportasion System Analysis", The MIT Press Cambridge, Massachusetts, and London, England. 1979.

9. Morlok, Edward K. "Pengantar Teknik dan Perencanaan Transportasi”, Penerbit Erlangga, Jakarta, 1995. 